\title{
Young university students and the knowledge about sexually transmitted infections ${ }^{a}$
}

\author{
Jovens universitários e o conhecimento acerca das infecções sexualmente transmissíveis \\ Jóvenes universitarios y el conocimiento sobre las infecciones por transmisión sexual
}

Vinícius Rodrigues Fernandes da Fonte ${ }^{1}$ (D) Thelma Spindola ${ }^{1}$ Márcio Tadeu Ribeiro Francisco ${ }^{1,2}$ Carolina Passos Sodré ${ }^{1}$ Nathália Lourdes Nepomuceno de Oliveira André ${ }^{1}$ Carina D'Onofrio Prince Pinheiro ${ }^{2}$

1. Universidade do Estado do Rio de Janeiro. Rio de Janeiro, RJ, Brasil.

2. Universidade Veiga de Almeida. Rio de Janeiro, RJ, Brasil.
Corresponding author:

Vinícius Rodrigues Fernandes da Fonte. E-mail: vinicius-fonte@hotmail.com

Submitted on 10/19/2017.

Accepted on 02/16/2018.

DOI: 10.1590/2177-9465-EAN-2017-0318

\section{Abstract}

Objective: To analyze the relationship between the social aspects of university students and the knowledge about the transmission of Sexually Transmitted Infections. Method: A cross-sectional descriptive study carried out at a university. The participants were university students aged 18 to 29 and with active enrollment. The stratified uniform sample was adopted by sex, making a total of 384 male students and 384 female students. The instrument of data collection used was a questionnaire. Data were analyzed using Software Statistical Package for the Social Sciences. Results: Young university students had knowledge below-average regarding Sexually Transmitted Infections, as for association with social aspects, female students, married or living together who had children and attended the health area, had more knowledge, being statistically significant $(p=<0.05)$. Conclusion: It is necessary to improve the health education strategies of the young university population.

Keywords: Sexually transmitted diseases; HIV; Knowledge; Young adult; Health education.

\section{Resumo}

Objetivo: Analisar a relação dos aspectos sociais de jovens universitários com o conhecimento acerca das formas de transmissão das infecções sexualmente transmissíveis. Método: Estudo descritivo transversal realizado em uma universidade. Os participantes foram os universitários na faixa etária de 18 a 29 anos e com matrícula ativa. Foi adotada a amostra estratificada uniforme por sexo, perfazendo um total de 384 estudantes do sexo masculino e 384 do sexo feminino. $O$ instrumento de coleta de dados utilizado fo um questionário. Os dados foram analisados com auxílio Software Statistical Package for the Social Sciences. Resultados: Os jovens universitários possuíam conhecimento abaixo da média em relação às infecções sexualmente transmissíveis, quanto à associação com aspectos sociais os estudantes do sexo feminino, casados ou que viviam juntos, que tinham filhos e cursavam a área da saúde possuíam mais conhecimento, sendo estatisticamente significativo $(\mathrm{p}=<0.05)$. Conclusão: É necessário melhorar as estratégias de educação em saúde da população jovem universitária.

Palavras-chave: Doenças sexualmente transmissíveis; HIV; Conhecimento; Adulto jovem; Educação em saúde.

\section{Resumen}

Objetivo: Analizar la relación entre los aspectos sociales de jóvenes universitarios y el conocimiento acerca de las formas de transmisión de las infecciones por transmisión sexual. Método: Estudio descriptivo transversal realizado en una universidad. Los participantes fueron los universitarios en el grupo de edad de 18 a 29 años y con matriculación activa. Se adoptó la muestra estratificada uniforme por sexo, totalizando 384 estudiantes del sexo masculino y 384 del sexo femenino. El instrumento de recolección de datos utilizado fue un cuestionario. Los datos fueron analizados con ayuda del software Statistical Package for the Social Sciences. Resultados: Los universitarios poseían conocimiento por debajo de la media con relación a las infecciones sexualmente transmisibles, en cuanto a la asociación con aspectos sociales los estudiantes del sexo femenino, casados o que vivían juntos, que tenían hijos y cursaban el área de la salud poseían más conocimiento, siendo estadísticamente significativo $(p=<0.05)$. Conclusión: Es necesario mejorar las estrategias de educación en salud de la población joven universitaria.

Palabras clave: Enfermedades de transmisión sexual; VIH; Conocimiento; Adulto joven; Educación en Salud. 


\section{INTRODUCTION}

Data from the Brazilian epidemiological bulletin on Human Immunodeficiency Virus (HIV) and Acquired Immunodeficiency Syndrome (AIDS) are understandable as regards the increase in numbers of HIV/AIDS infections in the young population, especially among men of different ages between 15 and 29 years old. ${ }^{1}$ In Brazil, HIV/AIDS is one of the few Sexually Transmitted Infections (STIs) that are included in the list of compulsory diseases, in this sense the incidence and prevalence of other infections are carried out through epidemiological studies, as in the cases of chlamydia, herpes, Human Papilloma Virus (HPV) and gonorrhea.

Nonetheless, data from the epidemiological bulletin on HIV/AIDS help in finding the young population as a population group vulnerable to STIs in biopsychosocial and programmatic aspects, considering that if the incidence or prevalence of STIs is high in a country or region, there is an increased risk of sexual transmission of HIV. ${ }^{2}$ As far as this study is concerned, the objective of research is the knowledge of university students about the forms of transmission of STIs.

Research ${ }^{3-9}$ points out that the university environment is predominantly composed of young people, and negative health behaviors during the academic period have been observed among them. The behavior acquired in universities is characteristic of the social, cultural, psychological and biological changes that young people undergo in the process of maturity.

As adolescence ends and university phase starts, it is common for young people to experience various new experiences that were previously forbidden or limited by their family. The initial periods of university student courses focus on the need to seek friendships and try to reconcile the new routine of commitments, studies and responsibilities. With a routine overloaded with previously unrealized activities and greater autonomy and freedom for young people, there are spaces to relax and have fun to relieve tension. In this sense, many university students seek at parties and events the feeling of relax necessary to face this whirlwind of events, promoting new forms of behavior and living life..$^{3,4}$

Despite a Brazilian reality, studies in African countries also recognize the vulnerability of young people in the university environment. Researchers in Ghana and Nigeria point out that students' lifestyles on the campus place them at a higher risk of contracting HIV, as pressure in the campus environment leads young people to get involved with casual sex. ${ }^{5,6}$

Studies ${ }^{7-10}$ point out that university students are vulnerable to STIs, due to the change in partners and sexual life commencement. The university scenario favors the appearance and consolidation of certain behaviors, especially related to the consumption of alcohol and other drugs and sexual meetings. The data describe that the consumption of psychoactive substances among university students is more frequent than in the general population, and its use increases the probability of experiencing situations of risk, among them unprotected sex.

Although the young population is considered vulnerable to numerous health problems, the university scene fosters, through socio-cultural aspects, the maintenance of these vulnerabilities, yet there is no policy focused on the context of this population. The articulation between health services and universities is still precarious and could be minimized if the interministerial (health and education) decree that instituted the HSP was extended to higher education in the country; however, it was restricted to basic education.

In this sense, health activities for young university students are either carried out by institutions themselves, through research or extension projects, or it is up to the university students themselves to seek access to the local health network. Regarding health education about STIs, research ${ }^{5,6,11-15}$ shows that the knowledge of university students about infections is low and most are not aware of the main symptomatology, forms of transmission and prevention, especially in infections of high incidence and information vehicles, such as chlamydia and trichomoniasis.

It is known that in the field of prevention, health education activities are essential. In this sense, considering the vulnerability of young people to STIs, the university environment, the low knowledge they have about STIs and the absence of a public policy directed at the demands of the university population, this study aims to analyze the relationship between the social aspects of young people and knowledge about the transmission of Sexually Transmitted Infections. Knowledge about STIs can be considered a marker for access to health education activities in this population.

\section{METHOD}

This is a cross - sectional descriptive study with quantitative approach. The research field was a university campus of a private institution in the city of Rio de Janeiro, which offers more than twenty-five university student courses, and had more than fifteen thousand university students with active enrollment until the first half of 2016.

The study participants were young university students who were regularly enrolled in university student courses. The population being $15-29$ years old is considered young according to the Statue of Youth, but in this study individuals under the age of 18 were not included because of legal issues that require the consent of those responsible for participation in research involving human beings. ${ }^{16}$

Inclusion criteria were to match the pre-established age bracket (18 to 29 years) and to have active enrollment in the respective university student courses offered by the Campus. People with visual impairment belonged to the exclusion criterion, since our Data Collection Tools (DCT) was not adapted in braille. 
Participants were selected through uniform stratified sampling by gender, since we did not obtain from the institution the quantitative number of students by age and gender to use the proportional stratified sampling. We used the conservative size for infinite populations to calculate the sample, and the confidence interval of $95 \%$ and sample error of $5 \%$ percentage points (pp) were established, obtaining a sample of 384 male students and 384 female students.

The DCT used was a questionnaire with 60 questions created and adapted for the population group studied, based on the study "Research on Behaviors, Attitudes and Practices of the Brazilian Population". ${ }^{17}$ This is a population survey commissioned by the Brazilian Ministry of Health, whose main objective was to enable the construction of indicators for monitoring the epidemic of STIs/AIDS in Brazil.

The dependent variables used were related to the evaluation of knowledge about STIs. The knowledge was assesses through an indicator constructed from four chunks of questions, with possibilities of yes or no answers, for infections caused by HIV, syphilis, hepatitis, gonorrhea, herpes, HPV and chlamydia. The chunks were: transmission through non-sexual contact, blood transmission and sharing of piercing objects, sexual transmission and possibility of cure. For this, a score of 0 (no knowledge) was set to 4 (total knowledge).

Knowledge was assessed through the median cut-off point. In this sense, it was considered as adequate knowledge who reached at least half of the maximum score, that is, greater than or equal to 2, and knowledge below the average those with a score lower than 2. The higher the score reached, the higher the knowledge.

Independent variables used in this research are related to social aspects.

The data were collected in June and July of 2016 in the campus of the selected university student. The approaches were carried out in the common areas (leisure areas, food court, sports court and corridors) and in classrooms after class and with the authorization of the professor responsible for the course. Filing out the questionnaire took an average of ten minutes. Students who agreed to participate had to respond and deliver the questionnaire at the same time as the researcher's approach.

The questionnaires were transcribed to a spreadsheet and turned into database using Excel 2003 Software features. Later, inferential analyzes were performed through the Software Statistical Package for the Social Sciences (SPSS). In order to verify the association between variables, Pearson's Chi-Squared Test was used for the dichotomous variables, with a significance level of $95 \%$, and the analysis of variance (ANOVA) for the comparison of the knowledge average with the other independent variables.
The study followed the requirements of National Health Council Resolution 466/12, which regulates the conduction of research involving human beings. The research was appreciated and approved by the Research Ethics Committee of the research headquarter University in the year 2016 with the Opinion number 1,577,311 and Certificate of Presentation for Ethical Consideration (Certificado de Apresentação para Apreciação Ética - CAAE) 56763316.1.0000.5291.

\section{RESULTS}

The majority of participants were non-health-related courses $(67.06 \%)$, while $32.94 \%$ were from the health area. Students in twenty-three university student courses participated in the study, with a greater proportion of participants in engineering courses (22.1\%), followed by nursing (19.9\%) and law $(9.8 \%)$.

The participants were between 18 and 21 years $(69.26 \%)$, the mean was 20.9 years and the standard deviation was 2.59 . In relation to marital status, the majority were single $(58.72 \%)$, had no children $(96.35 \%)$ and had white skin $(56.25 \%)$. In relation to gender, 654 (85.16\%) had an active sexual life and 114 (14.84\%) had not started their sexual life.

Regarding the knowledge about STIs, the participants presented below-expected knowledge, with a mean of knowledge in the evaluation used of 1.66 . No participant had a maximum score.

Table 1 compares social aspects of students and the level of knowledge regarding Sexually Transmitted Infections. It is possible to observe, through statistical significance, which gender $(p=0.0001)$, marital status $(p=0.008)$, children $(p=0.005)$ and type of knowledge area that is being attended in the university $(p=0.0002)$ are factors that are associated with the knowledge level about STIs.

The data in Table 1 indicate that the knowledge level is equal among university students composing this study, in relation to skin color and age bracket. As for the other variables, we can say that the knowledge level of students enrolled in health courses is $10 \%$ higher than students in other areas of knowledge. Regarding gender, female students have $9 \%$ more knowledge about STIs than males. Students who have children are $18 \%$ more knowledgeable than students who do not have children, and married students have more knowledge than single ones.

Table 2 shows the association between knowledge of university students on some STIs with the variables gender and age bracket. $(P=0.0001)$, gonorrhea $(p=0.041)$, herpes $(p=0.011)$, HPV $(p=<0.0001)$, and the prevalence of hepatitis and chlamydia $(p=<0.0001)$. In terms of age, young adults ( 25 to 29 years of age) reported more knowledge, being statistically significant in relation to syphilis $(p=0.015)$, hepatitis $(p=0.049)$ and chlamydia $(p=0.011)$. 
Table 1. Association between the social profile and the knowledge level of university students regarding the forms of transmission of STIs. Rio de Janeiro city, RJ, Brazil. 2016. (N=768)

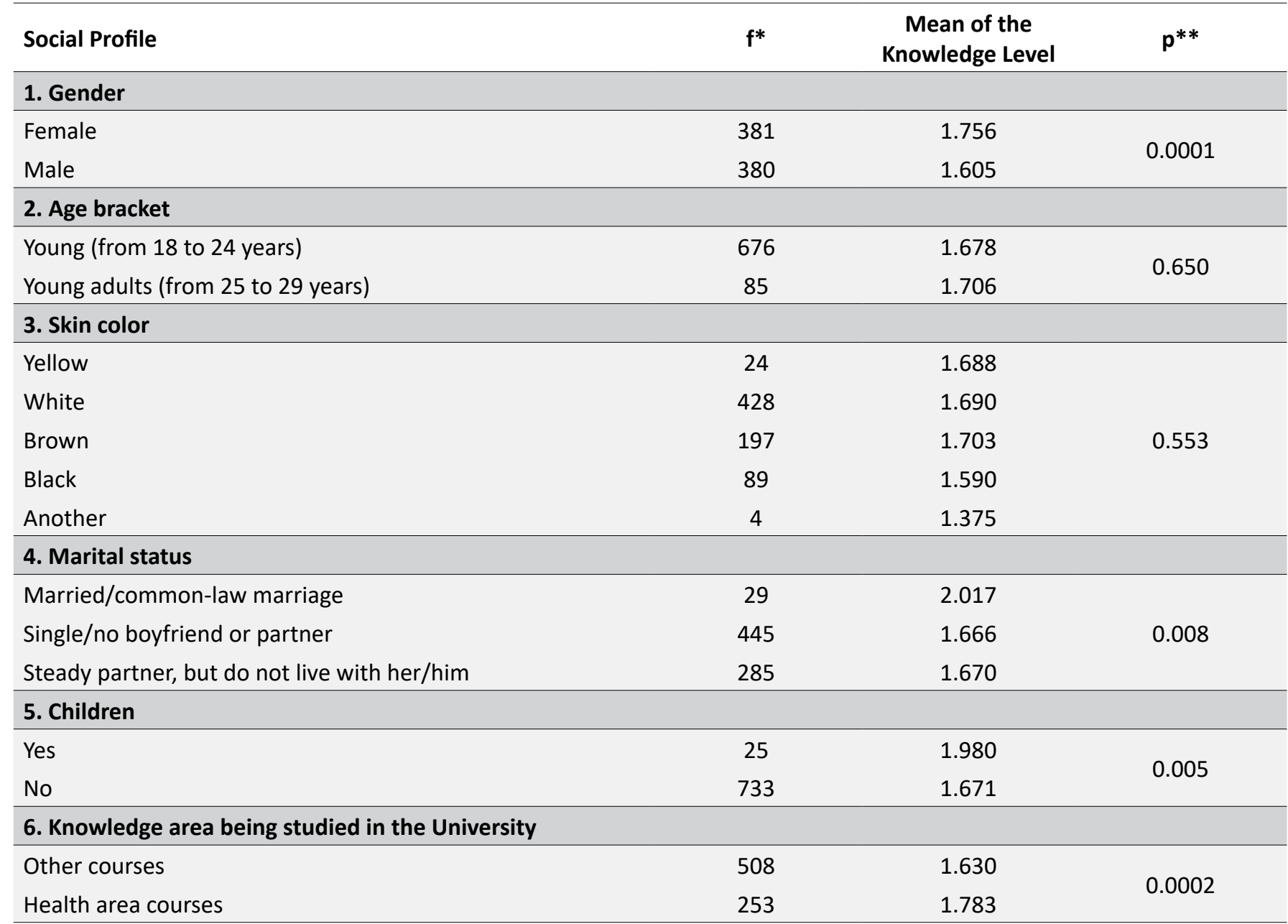

Source: Created by the authors, 2016. STIs: Sexually Transmitted Infections; ${ }^{*}$ The sum of results totals 768 , because some participants did not answer all the questions; ** ANOVA.

Table 2. Self-assessment of university students regarding the knowledge on the forms of transmission of STIs, associated to gender and age bracket. Rio de Janeiro city, RJ, Brazil. $2016(\mathrm{~N}=768)$

\begin{tabular}{|c|c|c|c|c|c|c|c|c|c|c|}
\hline \multirow{3}{*}{ Infections } & \multicolumn{5}{|c|}{ Gender } & \multicolumn{5}{|c|}{ Age Bracket } \\
\hline & \multicolumn{2}{|c|}{ Female } & \multicolumn{2}{|c|}{ Male } & \multirow[t]{2}{*}{$\mathbf{p}^{*}$} & \multicolumn{2}{|c|}{$\begin{array}{l}\text { Young (from } 18 \text { to } \\
24 \text { years) }\end{array}$} & \multicolumn{2}{|c|}{$\begin{array}{l}\text { Young adults (from } \\
25 \text { to } 29 \text { years) }\end{array}$} & \multirow[t]{2}{*}{ p* } \\
\hline & $f$ & $\%$ & $f$ & $\%$ & & $f$ & $\%$ & $f$ & $\%$ & \\
\hline AIDS & 380 & 98.96 & 377 & 98.18 & 0.182 & 673 & 98.54 & 84 & 98.82 & 0.417 \\
\hline Syphilis & 317 & 82.55 & 298 & 77.60 & 0.062 & 539 & 78.92 & 76 & 89.41 & 0.015 \\
\hline Hepatitis & 296 & 77.08 & 242 & 63.02 & 0.0001 & 471 & 68.96 & 67 & 78.82 & 0.049 \\
\hline Gonorrhea & 300 & 78.13 & 276 & 71.88 & 0.041 & 508 & 74.38 & 68 & 80.00 & 0.157 \\
\hline Herpes & 352 & 91.67 & 331 & 86.20 & 0.011 & 609 & 89.17 & 74 & 87.06 & 0.707 \\
\hline HPV & 321 & 83.59 & 239 & 62.24 & $<0.0001$ & 492 & 72.04 & 68 & 80.00 & 0.082 \\
\hline Chlamydia & 186 & 48.44 & 79 & 20.57 & $<0.0001$ & 222 & 32.5 & 43 & 50.59 & 0.011 \\
\hline
\end{tabular}

Source: Created by the authors, 2016. STIs: Sexually Transmitted Infections. * Pearson's Chi-Squared Test. 


\section{DISCUSSION}

Regarding social aspects, other researches are similar to the social profile of the university students participating in this study. The average age ranged from 19 to 22 years in the different studies analyzed, the majority of them were single, had whites or brown skin color and were Catholic. All the studies had greater female participation, however they showed a variation in the proportion between men and women when only health students were investigated. For historical and cultural reasons, health courses are more occupied by women. Having children ranged from $2.5 \%$ to $8.5 \%$ in the university population. ${ }^{3,8,11-18}$

Other research corroborates the data of this investigation, noting that university students still lack knowledge about STIs. A study with university students from the health area of Rio de Janeiro city identified that $58.5 \%$ of the students do not know all forms of STIs transmission, although $48.5 \%$ said they had the whole knowledge. ${ }^{11}$ In research with university students from São Paulo city was observed that $81 \%$ of the students had doubts about the symptomatology of the STIs. ${ }^{12}$ Research in Ribeirão Preto city, São Paulo State, with women students from a nursing university student course verified that, although $69 \%$ knew the forms of transmission of HPV only $20.7 \%$ said they knew some signs and symptoms. ${ }^{13}$ This phenomenon was also observed in university students in Turkey, where only $10 \%$ of the interviewees recognized that HPV is a risk factor for cervical cancer and that 90\% 9\% did not know how to protect themselves from HPV. ${ }^{14}$

In Portuguese research with university students in exchange, it was observed that $21 \%$ of participants did not know that STIs could be transmitted via oral sex. ${ }^{15}$ Studies with African university students have pointed out that universal awareness about HIV/AIDS does not imply knowledge and that misinformation, misunderstanding and doubts are still present in popular knowledge. Although knowledge is not a predictor of behavior change, yet access to information becomes a prerequisite for adopting preventive behavior. ${ }^{5,6}$

Research with Ghanaian university students in Africa on HIV/AIDS knowledge found that women had more knowledge than men, as well as young adults and married people had more knowledge than young people and singles, this phenomenon also observed in the present study. ${ }^{6}$ However, a study with university students in Nigeria found that men and older students had more knowledge about HIV/AIDS than women and younger students, yet women and older students were more willing to test for HIV. ${ }^{5}$

A study carried out in Colombia identifies that the degree of knowledge about STIs did not show a significant association with any variable studied. However, the degree of attitude towards STIs showed a significant association with the study area, being higher among health students and female students. While the association of attitudes and practices showed correlation with students' age and semester. Older students and advanced semester had higher scores on good attitudes and practices. ${ }^{19}$
In another Colombian study it was possible to identify that health students are the ones who use the condom the most, possibly due to their knowledge of STI be higher than among university students from other areas of knowledge. ${ }^{18}$

As for the infections that university students are more familiar with, the study describes that the most well-known STI among students at a university institution in Colombia were HIV, reported by $27.4 \%$ of the participants, followed by gonorrhea (24.1\%), syphilis $(22.1 \%)$, genital herpes (12.3\%) and HPV (7.5\%). However, although $96 \%$ of university students stated that they knew about the transmission of HIV, only $40.4 \%$ knew all of them. ${ }^{9}$ Other studies corroborate the present investigation by pointing out that HIV/AIDS is the most well-known STI among university students. Research conducted in Brazil with health professionals identified that most of the participants do not know infections such as chlamydia, chancroid, trichomoniasis, venereal lymphogranuloma, human T-lymphotropic virus (HTLV), and granuloma inguinale. ${ }^{20}$ While $42.3 \%$ of foreign university students in Portugal were unaware of the chlamydia sex infection. ${ }^{15}$

Although it is not the objective of this study, the results demand questions for the accomplishment of other data crossings that deepen discussions about the gender relations. After all, in this research it was possible to identify that women have a higher level of knowledge regarding STI than men.

As far as this study is concerned, the data, in agreement with the literature, point out that individual vulnerabilities are present in university students, through insufficient knowledge about STIs. It is also emphasized the social vulnerability, through the unequal relations between genders that have repercussions on the care with their health; and program vulnerability, where, even when attending higher education, they do not present satisfactory knowledge about STIs.

The study presents limitations, when portraying the reality of only one university campus and that did not obtain the participation of students of all the courses offered by the institution, considering that the present investigation was not intended to assess the courses. Thus, the data cannot be generalized to the university population of the whole country, although the results match other national and international investigations.

Another aspect that may be explored in future research is the relationship between the area of knowledge, which the university students are linked to, and the knowledge they have about STIs Although there is a statistically significant difference in the knowledge of the forms of STIs transmission among university students belonging to the health area and who belong to other areas, it was not the purpose of this investigation to address this issue alone, since a sample stratified by courses was not performed. However, some questions have arisen: Is the knowledge of university students in the health area greater by the offer of subjects that approach the subject? Would the provision of a sexual health course for university students in all areas of knowledge be effective in improving sexual knowledge and behavior? 
The data presented here portray the challenge of thinking about prevention with the current response in health education that has been employed. STIs have always been treated in a generalized and comprehensive manner, with the exception of HIV, which has been more prominent in prevention policies. The lack of visibility of infections, their respective forms of transmission, incidence, symptoms and consequences for health, provokes the struggle with the unknown and demands uncertainty and doubt among young people who cannot identify the danger that surrounds them. Other studies that have also dealt with the issue of confronting STIs with the university population indicate in their findings the need for investments in health education, since most of the interviewees have access to information only through media equipment (newspapers, television and radio). ${ }^{3.5,5,8,9,9,12,20}$

The findings showed that participants had more knowledge about HIV, however, other infections such as chlamydia, HPV and Herpes are still unknown to university students. It should be remembered that the infections mentioned are of high national prevalence and incidence, and even increase the chance of HIV infection.

In addition to HIV, efforts to address STI should consider efforts to bring visibility to other infections. In this case, the importance of health education is reinforced in order to deepen the dialogue with society in general. Currently, as HIV treatments progress, infections such as gonorrhea and chlamydia are becoming resistant to antibiotics.

In this sense, data from this research reinforce the need for educational activities with the young population; the inclusion of curricular subjects related to sexuality and the prevention of STIs; increased dialogue on neglected or poorly discussed/addressed STIs with the population; the political and cultural commitment to reduce gender inequalities and encourage men's participation in health care and respect for the health of their partners; and that the university, through its role in teaching, research and extension, contributes to the improvement of the knowledge of its students and, consequently, in the production and dissemination of information that promotes health to society.

It should be noted that enforcement for STIs must begin as soon as possible. Universities are just another space in front of a multitude of environments where prevention activities should be planned. Young people tend to initiate their sexual lives before entering universities, so prevention activities should be initiated in the family environment, in schools and in the spaces where children and adolescents coexist, preferably by trained professionals and with compatible teaching and learning techniques according to the age. Extension activities at universities are important to leverage science and improve coping, yet society, services in general, and politics must be engaged in this struggle.
It is important that health services consider universities as an area of intersectoral articulation to promote social mobilization in the face of STIs, as well as other aggravations affecting the young population. As members of society, we have a duty to assure the fundamental rights of the human person, and this includes sexual and reproductive rights. Sex and sexuality should be perceived as natural and free from censorship. We must deal with the subject by talking, listening and discussing, disposing of prejudices and moralities.

If we consider that the affective relationships in the present times are ephemeral, this reality becomes worrisome. Thus, we have a young population, with dreams, ideals and lots of energy, in search of new and vibrant experiences, willing to discover the world that surrounds them and to experience great and new emotions. In this context, to increase pleasure and emotions, they may be closer to other factors that tend to make them even more vulnerable to STIs, such as alcohol and drugs.

\section{CONCLUSION}

The research verified that university students have belowaverage knowledge about STIs, evidencing gaps in knowledge and justifying the importance of health education actions.

It was observed, in the inferential analyses, that the female, married or living with the partner, who have children and who attend health courses participants were those who showed a better score in the assessment of STIs. Single and male participants have lower knowledge scores regarding STIs.

The study ratifies the importance of nursing practice in the university environment and the need of health education as a pillar to face STIs since the beginning of university student course periods. With regard to the care of individuals, families and society, health education on STIs aims to promote adequate knowledge for the use of preventive methods; early identification of symptoms and timely search for treatment; curbing stigmas and prejudices; eliminate unequal gender relations and misogyny.

\section{REFERENCES}

1. Ministério da Saúde (BR). Departamento de IST, Aids e Hepatites Virais. Boletim epidemiológico HIV/aids. Brasília (DF): Ministério da Saúde; 2016. [cited 2017 Apr 8]. Available from: http://www.aids.gov.br/pt-br/ pub/2016/boletim-epidemiologico-de-aids-2016

2. Sychareun V, Thomsen S, Chaleunvong K, Faxelid E. Risk perceptions of STIs/HIV and sexual risk behaviours among sexually experienced adolescents in the Northern part of Lao PDR. BMC Public Health [Internet]. 2013; [cited 2017 Apr 8]; 13:1126. Available from: https://bmcpublichealth.biomedcentral.com/ articles/10.1186/1471-2458-13-1126. DOI: 10.1186/1471-2458-131126

3. Borges MR, Silveira RE, Santos AS, Lippi UG. Sexual behaviour among initial academic students. J Res Fundam Care Online [Internet] 2015 Apr/Jun; [cited 2017 Apr 8]; 7(2):2505-15. Available from: http:// www.seer.unirio.br/index.php/cuidadofundamental/article/view/3676/ pdf_1588. DOI: 10.9789/2175-5361.2015.v7i2.2505-2515 
4. Gomes VLO, Amarijo CL, Baumgarten LZ, Arejano CB, Fonseca $\mathrm{AD}$, Tomaschewski-Barlem JG. Vulnerability of nursing and medicine students by ingestion of alcoholic drinks. J Nurs UFPE On Line [Internet] 2013 Jan; [cited 2017 Apr 8]; 7(1):128-34. Available from: https:// periodicos.ufpe.br/revistas/revistaenfermagem/article/view/10213/0. DOI: 10.5205/reuol.3049-24704-1-LE.0701201318

5. Abiodun O, Sotunsa J, Ani F, Jaiyesimi E. Knowledge of HIV/AIDS and predictors of uptake of HIV counseling and testing among university student students of a privately owned university in Nigeria. BMC Res Notes [Internet]. 2014; [cited 2017 Apr 8]; 7:639. Available from: https:// bmcresnotes.biomedcentral.com/articles/10.1186/1756-0500-7-639. DOI: $10.1186 / 1756-0500-7-639$

6. Asante KO. HIV/AIDS knowledge and uptake of HIV counselling and testing among undergraduate private university students in Accra, Ghana. Reprod Health [Internet]. 2013; [cited 2017 Apr 8]; 10:17. Available from: https://reproductive-health-journal.biomedcentral.com/ articles/10.1186/1742-4755-10-17. DOI: 10.1186/1742-4755-10-17

7. Shiferaw Y, Alemu A, Assefa A, Tesfaye B, Gibermedhin E, Amare M. Perception of risk of HIV and sexual risk behaviors among University students: implication for planning interventions. BMC Res Notes [Internet]. 2014; [cited 2017 Apr 8]; 7:162. Available from: https:// bmcresnotes.biomedcentral.com/articles/10.1186/1756-0500-7-162. DOI: 10.1186/1756-0500-7-162

8. Díaz-Cárdenas S, Arrieta-Vergara K, González-Martínez F. Prevalencia de actividad sexual y resultados no deseados em salud sexual y reproductiva en estudiantes universitarios em Cartagena, Colombia, 2012. Rev Colomb Obstet Ginecol [Internet]. 2014 Mar; [cited 2017 Apr 8]; 65(1):22-31. Available from: http://www.scielo.org.co/scielo. php?script=sci_arttext\&pid=S0034-74342014000100004\&Ing=es\&nr $\mathrm{m}=$ iso\&tlng=es. DOI: http://dx.doi.org/10.18597/rcog.76

9. Gómez-Camargo DE, Ochoa-Diaz MM, Canchila-Barrios CA, Ramos-Clason EC, Salguedo-Madrid GI, Malambo-García DI. Salud sexual y reproductiva en estudiantes universitarios de una institución de educación superior en Colombia. Rev Salud Pública [Internet]. 2014; [cited 2017 Apr 8]; 16(5):660-72. Available from: http://www.scielosp.org/scielo.php?script=sci_arttext\&pid=S012400642014000500002\&lng=en. DOI: http://dx.doi.org/10.15446/rsap. v16n5.39998

10. Spindola T, Fonte VRF, Martins ERC, Francisco MTR, Sodré CP, Oliveira CSR. Práticas sexuais, uso do preservativo e testagem para o HIV entre graduandos de enfermagem. Rev Enferm UFSM [Internet] 2017 Oct/Dec; [cited 2017 Apr 8]; 7(3):477-89. Available from: https:// periodicos.ufsm.br/reufsm/article/view/25736/pdf. DOI: http://dx.doi. org/10.5902/2179769225736

11. Dantas KTB, Spindola T, Teixeira SVB, Lemos ACM, Ferreira LEM. Young academics and the knowledge about sexually transmitted diseases contribution to care in nursing. J Res Fundam Care Online [Internet]. $2015 \mathrm{Jul} / \mathrm{Sep}$; [cited 2017 Apr 8]; 7(3):3020-36. Available from: http:// www.seer.unirio.br/index.php/cuidadofundamental/article/view/4689/ pdf_1666. DOI: 10.9789/2175-5361.2015.v7i3.3020-3036
12. Castro EL, Caldas TA, Morcillo AM, Pereira EMA, Velho PENF. O conhecimento e o ensino sobre doenças sexualmente transmissíveis entre universitários. Ciênc Saúde Coletiva [Internet]. 2016; [cited 2017 Apr 8]; 21(6):1975-84. Available from: http://www.scielo.br/ pdf/csc/v21n6/1413-8123-csc-21-06-1975.pdf. DOI: 10.1590/141381232015216.00492015

13. Panobianco MS, Lima ADF, Oliveira ISB, Gozzo TO. Knowledge concerning HPV among adolescent undergraduate nursing students. Texto Contexto Enferm [Internet]. 2013 Jan/Mar; [cited 2017 Apr 8] 22(1):201-7. Available from: http://www.scielo.br/scielo.php?script=sci arttext\&pid=S0104-07072013000100024\&lng=en\&nrm=iso\&tlng=en DOI: http://dx.doi.org/10.1590/S0104-07072013000100024

14. Koç Z. University student's knowledge and attitudes regarding cervical cancer, human papillomavirus, and human papillomavirus vaccines in Turkey. J Am Coll Health [Internet]. 2015; [cited 2017 Apr 2]; 63(1):13-22. Available from: http://www.tandfonline.com/doi/abs/10.1080/07448481 .2014.963107. DOI: http://dx.doi.org/10.1080/07448481.2014.963107

15. Gravata A, Castro R, Borges-Costa J. Study of the Sociodemographic Factors and Risky Behaviours Associated with the Acquisition of Sexual Transmitted Infections by Foreign Exchange Students in Portugal. Acta Med Port [Internet]. 2016 Jun; [cited 2017 Apr 2]; 29(6):360-6. Available from: http://www.actamedicaportuguesa.com/revista/index.php/amp/ article/view/6992. DOI: http://dx.doi.org/10.20344/amp.6692

16. Brasil. Lei №. 12852, de 05 de agosto de 2013. Institui o Estatuto da Juventude e dispõe sobre os direitos dos jovens, os princípios e diretrizes das políticas públicas de juventude e o Sistema Nacional de Juventude - SINAJUVE. Brasília (DF): Diário Oficial da República Federativa do Brasil; 2013.

17. Ministério da Saúde (BR). Departamento de IST, Aids e Hepatites Virais. Pesquisa de conhecimentos, atitudes e práticas na população brasileira 2008. Brasília (DF): Ministério da Saúde; 2011 [cited 2017 Apr 8]. Available from: http://bvsms.saude.gov.br/bvs/publicacoes/ pesquisa_conhecimentos_atitudes_praticas_populacao_brasileira.pdf

18. Rodríguez DEC, Varela YP. Percepciones que afectan negativamente el uso del condón en Universitarios de la Costa Caribe Colombiana. Hacia Promoc Salud [Internet]. 2014; [cited 2017 Apr 8]; 19(1):5467. Available from: http://www.scielo.org.co/scielo.php?script=sci_ arttext\&pid=S0121-75772014000100005\&lng=es\&nrm=iso\&tlng=es

19. Mazo-Vélez Y, Domínguez-Domínguez LE, Cardona-Arias JA. Conocimientos, actitudes y prácticas en adolescentes universitários entre 15 y 20 años sobre VIH/SIDA en Medellín, Colombia 2013. Med UIS [Internet]. 2014 Sep/Dec; [cited 2017 Apr 8]; 27(3):35-45. Available from: http://www.scielo.org.co/scielo.php?script=sci_arttext \&pid=S0121-03192014000300005

20. Sales WB, Caveião C, Visentin A, Mocelin D, Costa PM, Simm EB. Comportamento sexual de risco e conhecimento sobre IST/SIDA em universitários da saúde. Rev Enferm Ref [Internet]. 2016 Sep; [cited 2017 Apr 2]; 4(10):19-27. Available from: http://www.scielo.mec.pt/ scielo.php?script=sci_arttext\&pid=S0874-02832016000300003. DOI: http://dx.doi.org/10.12707/RIV16019

a Extracted from Masters dissertation entitled "Sexual conduct of young university students and knowledge regarding Sexually Transmitted Infections". Presented at the State University of Rio de Janeiro in December 2016. 